\title{
French Feminists Renegotiate Republican Universalism: \\ the Gender Parity Campaign
}

\author{
Laure Bereni
}

Published in French Politics, 5(3), 2007, p. 191-209.

\section{Introduction}

For the first time in its legal history, France has an affirmative action policy to help women gain political representation ${ }^{1}$, mandated by a constitutional amendment in 1999 and an electoral law in 2000. In this respect, France is not an "exception". These laws are the national translation of a process of redefining the categories of gender equality and fair representation that was already under way in international organizations and in many neighboring democracies (Lovenduski, 2005; Sawer et al., 2006). However, the French campaigns for "parity" (parité), and the controversies they triggered before the laws were enacted, also have a specifically French history. How did parity progress, in less than a decade, from a utopian demand to a consensual reform? At the beginning of the 1990s, the rallying cry of parity beginning to be heard in France was perceived as quite utopian: it was supported by a small minority of feminist activists, in a country that stood out, among western liberal democracies, for its highly male-centered political system and its dramatic under-representation of women. Less than ten years later, two institutional reforms forcing political parties to introduce sexbased quotas in their slates of candidates received almost unanimous support in the Parliament. Even if some of the proponents of parity's hopes turned out to be disappointed (Bird, 2003; Murray, 2004; Lépinard, 2006, 2007b), it is clear that the adoption of the constitutional amendment and the electoral law in 1999-2000 was a major success for the "movement" for parity. 
Identifying the conditions of the success of mobilizations is arguably one of the main tasks for those engaged in comparative studies of women's movements (Mazur, 2001), and of social movements generally (Della Porta and Diani, 2006). Ideational approaches (Bacchi, 1999; Benford and Snow, 2000) have drawn "attention to the impact of ideas, norms and language upon policy-making processes and outcomes" (Bacchi, 2004: 129) among the factors in such a success. In emphasizing that "ideas and knowledge constitute important resources for interest groups", these authors aim to supplement "interest-based and institutional accounts of the policy-making process" (Mazey, 2000: 338). A prolific body of research on women's movements has attempted to integrate these discourse-focused approaches (Riley, 1988; Scott, 1996, 2005; Mazur, 2002; Ferree, 2003). Applying them to the French case, historians have mostly focused on the interaction between the dominant paradigm of "republican universalism" and feminist challenges to women's subordination since the French Revolution (Landes, 1988; Fraisse, 1989; Scott, 1996; Bereni and Lépinard, 2003, 2004; Scott, 2004, 2005; Lépinard, 2006, 2007a, 2007b). "Republican universalism" can be defined as a set of principles rooted in the formative experience of the French Revolution, specifically in the 1789 "Déclaration des Droits de l'Homme et du Citoyen" (Declaration of the Rights of Man and of the Citizen). While its meaning is constantly renegotiated in each historical context in which it operates, republican universalism presents itself as a set of immutable norms, informing legitimate political discourses and practices, especially since the consolidation of the Republican regime in the first years of the $20^{\text {th }}$ century. Resting on a double abstraction, of the individual and of the nation (Scott, 2004), Republican universalism has been analyzed as a recurrent discursive obstacle to women's demands for inclusion. As Amy Mazur puts it, the universalist doctrine in place since the French Revolution proved to be "gender-biased" as much as "gender-blind" (Mazur, 2005: 212). Almost a century elapsed between the time when adult men were granted the "universalist" right to vote and to stand for office (1848) and the 
enfranchisement of women (1944). While some historians have attributed this specificity to the backwardness of social mores compared to the "radicality" of universalist political principles (Rosanvallon, 1992), feminist studies of French political history have shown that the exclusion of women was an implicit cornerstone of the modern liberal, universalist model (Landes, 1988; Fraisse, 1989; Scott, 1996). In Only Paradoxes to Offer (1996), Scott emphasized the coexistence of two contradictory universalisms within the modern French political regime: the universalism of "abstract" individual rights, which does not accept any collective identity within the political realm, and the universalism of "sexual difference", based on the idea that women are naturally and absolutely different. Justifying the subordination of women in the private sphere and the exclusion of women from the public sphere, this dual, contradictory discourse is echoed in the paradoxical dimension of feminist discourses arguing in favor of political inclusion since the French Revolution - the need both to accept and to reject sexual difference. Yet, analysts of French women's movements ${ }^{2}$ have also insisted that this dominant universalist ideology has often been manipulated and twisted by feminists, particularly by suffragists under the Third Republic, who expressed their demands in the name of, and within, the republican discursive framework (Klejman and Rochefort, 1989; Bard, 1995; Scott, 1996; Offen, 2000).

In line with these perspectives, drawing on an analysis of the campaigns and debates occasioned by the demand for parity in the $1990 \mathrm{~s}$, this article is a contribution to the literature on the relationship between feminism and republican universalism (Bereni and Lépinard, 2003; 2004; Scott, 2004, 2005; Lépinard, 2006, 2007a, 2007b). A first section reviews the history of the campaigns for a better inclusion of women in politics since the emergence of the second wave of feminism, from the failure of the demands for quotas to the success of the claim of parity. A second section looks at the discursive tactics used by the proponents of 
parity to shape their claim within the terms of the dominant republican universalist discourse - at how they strove to fit themselves into republican universalism, and in so doing renegotiate its meaning, in order to secure their claim. The third section is a discussion of Joan Scott's recent analysis of the "refiguration" of universalism in the discourses of the advocates of parity (paritaristes) (Scott, 2004, 2005). While in agreement with many aspects of her analysis, I question the idea of an "essentialist" shift, within the movement for parity, from the rhetoric of "anatomical dualism", which she attributes to "initial" paritaristes, to that of "sexual difference", adopted by "followers". I would attempt to show that even those proponents of parity closest to abstraction were to some extent caught up in the "dilemma of difference".

\section{Claiming women's inclusion in politics since the Second Wave: From quota to parity}

\section{The failure of quota}

The singular French backwardness as regards the inclusion of women in the political sphere did not vanish after they eventually gained access to formal citizenship in 1944. In spite of decreasing differences in female and male attitudes toward electoral politics (Mossuz-Lavau, 1993), the proportion of women in the Parliament never exceeded 6 per cent during the fifty years that followed the moment when women were eventually granted suffrage and the right to run for office (from 1944 to 1994), leaving France next-to-last among all European countries in the mid-1990s ${ }^{3}$. However, between the accession of women to formal citizenship and the beginning of the campaign for parity in the early 1990s, the issue of the representation of women in the political system was not a central concern, neither of the women's 
movements nor of the key political and institutional players. When it emerged in the early 1970s as a mostly "radical" development, the French second-wave women's movement was mainly reluctant to play the game of formal political representation (Picq, 1993; Giraud, 2005). During the 1970s, the issue of the representation of women was raised by only a few, symbolically dominated factions of the women's movement: a handful of women's organizations ("associations féminines") from the tradition of first-wave feminism demanded better "integration" of women in the "city", and some women who were party members - but only a minority - voiced a demand for a sex-based quota to increase the proportion of women in electoral politics (Praud, 1997; Allwood and Wadia, 2000; Bereni, 2006b, 2007; Opello, 2006). This demand was first made within the Parti socialiste (PS) by a few female party executives, including Marie-Thérèse Eyquem and Yvette Roudy, who defined themselves as both "feminist" and "socialist". Thanks to their strong links with the new PS leader, François Mitterrand, they obtained the inclusion of a sex-based quota applying to the party's leadership positions and candidacies in the party's internal rules. Initially set at ten percent (1974), it was raised to 30 percent (1990) under the constant pressure of feminist activists within the organization. Born in the PS, the idea of a quota was also promoted by a few "feminine" right-wing activists in the late 1970s, including the Gaullist women's organization "Femme Avenir", which supported - unsuccessfully - a 30 percent sex-based quota in party organization and candidacies by 1979 .

However, the French history of sex-based quotas is a history of failure. Quotas were never accepted by the elites of the right-wing parties, and they never led to actual equality between men and women in leadership positions within the Socialist party (Appleton and Mazur, 1993; Opello, 2006). Moreover, in 1979 and 1982, two attempts to impose sex-based quotas - made under right- and left-wing governments, respectively - failed. In 1978, a bill sponsored by 
Monique Pelletier, the head of the Ministry of Women's Issues under a right-wing government, creating a 20 percent sex-based quota on municipal lists, was proposed; but because of a critical lack of political support it failed to survive the complete legislative process. Then, in 1982, Gisèle Halimi, a prominent feminist activist from the moderate wing of the autonomous women's movement, made a new attempt. After being elected to the National Assembly, she persuaded the socialist "caucus" (groupe) to introduce an amendment stating that party candidate lists in local elections should include no more than 75 percent of persons of the same sex. Although the amendment was adopted almost unanimously, it was overruled by a decision of the Constitutional Council (Conseil Constitutionnel) on November 18, 1982. The Council stated that two of the founding principles of the French Republic (article 6 of the Déclaration des Droits de l'Homme et du Citoyen and article 3 of the French Constitution of 1958) were "opposed to any division of voters or candidates by category" (Décision no 82-146 DC du 18 novembre 1982). Reinforcing the legal basis of the standard discourse of gender-neutral republican equality, the Council's ruling made it hard for feminist party members to maintain the case for affirmative action and thereby put an end to demands for quotas (Baudino, 2005; Scott, 2005). Even prior to this constitutional failure, the quota rhetoric had shown little ability to work as a rallying cry for the women's movement. While supported by a small minority of women party-members, it was dismissed as a "humiliating" measure by most female politicians and as not "radical" enough by the majority of the secondwave women's movement. Moreover, even in the view of its supporters, quotas were never described in a purely positive way. Roudy, for example, presented the sex-based quota as a temporary strategy, a provisional waiver of "republican" principles. In her view, in line with the universalist perspective inherited from Simone de Beauvoir, the goal of feminism was to free women from their specific gender roles and allow them to be fully integrated in the common mold of abstract citizenship (Thébaud, 2001). 
Thus, until the emergence of the motto of parity in the early $1990 \mathrm{~s}$, the doctrine of genderneutral republican universalism operated so as to bar women's claims for political inclusion, then mostly phrased in terms of "quotas". In contrast, the 1990s witnessed the emergence and the spread of the new slogan of "parity", paradoxically conceived as a departure from the logic of quotas, which turned out to have a much deeper resonance both in the women's movement and in the mainstream public space.

\section{Parity: From utopian demand to consensual reform}

While inspired by the concern for gender equality in political representation that was growing in international organizations and in many European democracies in the 1980s, parity is a "homegrown French concept" (Mazur, 2001: 224). It was first used in the 1980s by German and French environmentalist groups (German "Grünen", French "Arc-en-ciel", and "Les Verts") under pressure from their feminist activists, to name a set of practices intended to promote equality between men and women within the organization. However, the term "parity" was first construed as a "new democratic" principle by French philosopher Elisabeth G. Sledziewski in her introductory report to a seminar on "Gender parity in Democracy" held in Strasbourg in November 1989 by the "Equality Committee" of the Council of Europe. In her report, Sledziewski castigated the dominant gender-blind conception of equality, in which it is assumed that preferential treatment for women - if there is to be any - must be a temporary exception to the grounding political principles. Rather, she advocated that equality between men and women (which she called "parity") should be considered a "political prerequisite, pertaining to the constitutive principles of the regime, exactly like universal suffrage and the separation of powers" (Sledziewski, 1992: 23-26). In line with Sledziewski's 
theorizing, the publication in 1992 of the book Au pouvoir, citoyennes! Liberté, égalité, parité by feminist activists Françoise Gaspard, Claude Servan-Schreiber, and Anne Le Gall introduced the "concept" of parity to a wider audience in France and spelled out its practical meaning. The authors defined parity as the demand for a law imposing "perfect equality", i.e. a fifty-fifty representation of the sexes, in all representative assemblies (Gaspard et al., 1992). On November 2-3, 1992, a conference on "Women in Political Power" was held in Athens under the auspices of the European Commission. It produced a "Declaration" signed by twenty prominent European female politicians, stating that "democracy imposes parity in the representation and in the administration of the nations". In France this event catalyzed the rise of a "movement" for parity, gathering women activists from heterogeneous backgrounds (members of autonomous "feminist" and "feminine" organizations, members of the women's groups of the different political parties, feminist scholars, femocrats, etc.) around the same slogan. In the following years, a flurry of new women's groups (including "Parité", "Parité 2000", "Parité-infos", “Assemblée des femmes”) and networks of women's organizations (such as "Elles Aussi”, "Réseau Femmes pour la parité”, "Demain la Parité”, "Réseau Femmes et Hommes pour la parité") supported the motto. Although it attracted a number of party women, the campaign for parity took place outside the political parties, in independent organizations and networks. From 1993 to 2000, they pressured political parties, government leaders, and the media, using various - mainly conventional - venues, including conferences and meetings, manifestos, letter-writing campaigns to political leaders, newsletters, newspaper articles, demonstrations in front of the Parliament, etc. Among the most visible activities were two press manifestos: the "Manifeste des 577 pour une démocratie paritaire" (Manifesto of the 577 for a parity democracy) published in the daily newspaper Le Monde on November 10, 1993 and signed by 289 women and 288 men (577 is the number of "députés" in the National Assembly); and the "Manifeste des dix pour la parite" (Manifesto of the ten 
for parity) in the weekly L'Express of June 6, 1996, signed by ten prominent French women politicians, all former ministers, from the major political parties (both wings). Although parity occasioned serious disagreement among French feminist intellectuals (see Amar, 1999), several of them - for example Sylviane Agacinski, Geneviève Fraisse (both philosophers), Michelle Perrot (historian), Janine Mossuz-Lavau (political scientist), and Julia Kristeva (cultural theorist) - publicly committed to parity by publishing articles and essays in the mainstream public arenas (media, political, and academic $)^{5}$.

This mobilization around the motto of parity, encouraged by a series of public opinion polls by the second half of the $1990 \mathrm{~s}^{6}$, led to a progressive legitimization of the slogan, whereas the notion of quota had previously received little support in mainstream politics. As early as June 1994, six lists presented at the European election were "paritaires", including that of the PS. In the presidential campaign one year later, the slogan of parity gained support from the main candidates. Once elected, Jacques Chirac fulfilled an electoral pledge by creating, in October 1995, the "Observatoire de la parité entre les femmes et les hommes" (Observatory of parity between women and men), a state-level body aimed at developing strategies to increase women's presence in politics. In December 1996, the Observatoire produced an important report arguing for a revision of the Constitution and for a law imposing sex-based quotas in candidacies (Observatoire de la parité, 1996). While the right-wing government remained indifferent to these recommendations, the leading opposition party at that time, the PS, rallied to parity. The increasing weight of the theme of "institutional renovation" in the PS platform since its dramatic defeat in 1993 was a reason for the growing attention paid to the better representation of women, expected to bring about a renewal in political practices and ideas (Opello, 2006). In 1996, under the new leadership of Lionel Jospin, the PS enshrined the goal of parity in its program - significantly, not in the section devoted to women but in the section 
on the renovation of democracy (Parti socialiste, 1996) ${ }^{7}$. The party also decided, for the first time in its history, to set aside almost 30 percent of candidacies for women in the following legislative election, which took place in May-June 1997. This strategy proved successful and helped produce the unexpected electoral victory of the PS. In June 1997, the new Socialist Prime Minister, Lionel Jospin, announced in his first major political speech ("Déclaration de politique générale") that he intended to revise the Constitution in order to include a parity clause. Fulfilling this pledge, the government in June 1998 sponsored a constitutional bill on "the equal access" of women and men to electoral mandates. This aroused intense public controversy among intellectual and political elites - mainly in the press and the parliamentary arena - in the following two years (1998-2000). The opponents of the constitutional reform there were many of them in the Senate's right-wing majority - were eventually defeated by the pressure of feminist activists, the leaders of both majorities (Lionel Jospin and Jacques Chirac), and the media (which often described the Senate as reactionary and pointed out the women's suffrage had repeatedly been rejected by a majority of senators in the interwar years). The Parliament adopted the constitutional reform in June 1999. About one year later, the electoral law of June 6, 2000 defining the specifics of the legislation - a mix of constraints and incentives - was enacted without arousing much public controversy. Although these laws - as the products of a political compromise - diluted many of the initial aspirations underlying the reform (Lépinard, 2006, 2007b), most proponents of parity considered that they had achieved their goal after the 2000 electoral law, and most of the pro-parity women's groups then faded away.

\section{Parity: a battle over the meaning of universalism}


The existing literature on the movement for parity documents the variety of factors that played a role in the legitimization and institutionalization of the claim, such as the work of mobilization by various players in the women's movement (Giraud, 2005; Bereni, 2007; Lépinard, 2007b), the existence of a "window of opportunity" opened by the crisis of representation in French politics in the 1990s (Giraud and Jenson, 2001; Bereni and Lépinard, 2004; Scott, 2005), and the impact of international influences (Bereni, 2004; Krook, 2007; Lépinard, 2007b). Most accounts of the success of parity also emphasize the crucial role of the framing strategies in support of the claim (Bereni and Lépinard, 2004; Scott, 2005; Lépinard, 2007b). In line with this perspective, this section shows that proponents of parity, faced by a revitalized rhetoric of universalism, engaged in a discursive work ${ }^{8}$ allowing their claim to resonate with this dominant category of the political discourse.

\section{A revitalized universalism in the 1990 s}

The campaign for parity developed in the wake of the rekindling of "republican universalist" discourses, a salient feature of the intellectual public spheres in the 1980s and 1990s (Scott, 2004; Scott, 2005; Lépinard, 2007; Lépinard, 2007). While the notions of "republic" and "universalism" had mostly been rejected as reactionary by the Marxian frames that dominated the intellectual life of the social movements in the aftermath of May 1968, they once again became a major topic for academic research and a legitimate reference for intellectuals and politicians. This shift took place in the context of a decline of leftist ideologies by the end of the 1970s, along with the beginning of the collapse of the communist regimes at the turn of the 1990s, which seemed to leave liberal democracy as the only viable political model. In addition, the bicentennial of the French Revolution, celebrated in 1989, favored a rediscovery of the "republican" legacy. Scott relates this renewal of republican ideology to the "crisis" 
experienced by the French "nation" in the 1980s-1990s, under several pressures, both external (the decline of national sovereignty in a context of economic globalization and European construction) and internal (the crisis of the French "integration model", as reflected by the rise of protests by second-generation North African immigrants and the increasing popularity of the extreme right) (Scott, 2005). In this context, the period witnessed an intellectual mobilization in support of a specifically French model, the "Republic". In the 1980s, a large body of historical research explored the aftermath of the French Revolution and the “republican" legacy (e.g. Nora, 1984; Furet, 1989). In the 1990s, a set of sociological and philosophical inquiries helped define the Republic as the means to deal with the challenges that the French nation had to face, such as "integration" and "representation" (e.g. Schnapper, 1994; Spitz, 1997). This reassessment of the republican model coincided with the redefinition of the French "exception", as opposed to the American model (Fassin, 2001). Some influential French intellectuals identified America as the embodiment of the two alternative approaches against which the French identity ought to be defined, namely "multiculturalism" and "liberalism" (e.g. Raynaud, 1992; Jelen, 1997). On the one hand, the French political model, based on a constructivist view of the community of citizens (created in part through the Republican public school), was presumed to be opposed to the tradition of individualistic liberalism, in which the State plays a minimal role. On the other hand, the French model was allegedly contrary to "communitarianism" ("communautarisme") and "multiculturalism", since it is based on a strict separation between "society" and "politics", and recognizes only citizens in the abstract.

\section{Universalizing sexual difference}


While the republican universalist discourse was not the only obstacle to the claim of parity ${ }^{9}$, it was one of the most visible references of anti-parity arguments in the public debate. This commitment to republican universalism was worked out by self-proclaimed feminist intellectuals making the case for a "universalist feminism", such as philosopher Elisabeth Badinter (1996) and political scientist Evelyne Pisier (1999), and by prominent intellectuals not identified as feminists (see e.g. Minc, 1997; Roudinesco, 1999). Beyond their ideological divergences, they carried a common message: republican universalism made it impossible to dismiss the gender-blind dimension of political representation. Referring directly to the Constitutional Council's ruling of 1982, they asserted, as Joan Scott puts it, that "the fiction that individuals have no sex (and that sex is equivalent to any other social characteristic) had to be maintained in politics" (Scott, 2005: 73). Not only would parity be an unacceptable intrusion of gender into politics, but it would also open the "Pandora's box of particular claims", i.e. entail a general breakdown of the national sovereignty into as many categories as there are social groups. According to Elisabeth Badinter, "the argument [of parity] introduces a fatal drift in our secular and universalist Republic. [This is so b]ecause the numerical argument will inevitably lead to parity claims from other communities, racial, religious, even cultural and sexual" (Badinter, 1996: 15). In sum, "republican" opponents to the reform framed the debate as a stark choice between parity and French republican universalism.

Faced with these recurrent arguments, which had been responsible for the failure of quotas in the early 1980s, parity advocates recurrently rejected the idea that their claim was a form of "quota" or "affirmative action". They presented their demand as a deepening of, rather than a derogation from, the universalist framework. To do so, proponents of parity redefined the status of "sexual difference" (différence sexuelle), from then on described as an immutable principle prevailing over all other differences (e.g. class, age, ethnicity, race, etc.). In support 
of this conception, they used three main arguments (Bereni and Lépinard, 2004). First, a statistical argument: because women had always constituted at least "half of humanity", they could not, unlike ethnic groups for example, be equated with a disadvantaged "minority" such as may be targeted by affirmative action programs. Second, the specific status of gender difference was based, for many proponents of parity, on a technical argument: the fact that, unlike many other distinctions, gender groups have clearly and easily identifiable frontiers, since gender is one of the permanent characteristics of the civil identity of each individual. As parity campaigner Françoise Gaspard wrote: "categorization as male or female cannot be regarded as comparable to social status, religion, or skin color - contingent features that are not taken into account in the civil status of individuals. The division into sexes has a very special character" (1998: 27). Last but not least, supporters of parity repeatedly used an anthropological argument. According to this argument, the sexual divide structures all known societies, and the sexual bi-categorization is a permanent, "universal" characteristic of humanity itself. Parity's champions in the media and parliamentary public debates endlessly raised this argument. For example, Gisèle Halimi wrote: "women are not a community, and have among themselves no community ties as they are defined by social scientists. They are not a race, not a class, not an ethnic group, not a category. They belong to all these groups, engender them, cut across them. Sexual difference is the original parameter. Before being of a class, a race, a corporation, etc., a human being is first of all female or male" (1997: 14). In sum, opposing sexual difference to diversity, proponents of parity managed to define the gender divide as the only acceptable criterion of distinction in a universalist, republican framework, and to make their claim a genuine French product, defined in self-conscious opposition to the American model (Scott, 1997; Fassin, 1999; Bereni and Lépinard, 2004; Lépinard, 2006, 2007a, 2007b). At the same time, by asserting that the abstract citizen was either female or male, they contributed to a redefinition of republican universalism. 


\section{Difference or dualism: the persistent paradoxes of feminist challenges to universalism}

\section{"Anatomical dualism" vs. "sexual difference"}

In her recent book Parity! Sexual Equality and the Crisis of French Universalism (2005), Joan Scott explores in a very subtle way the enormous controversy occasioned by the emergence of parity in the intellectual, media and political arenas in the course of the 1990s. Continuing a thesis that she had developed in previous works on French feminism (Scott, 1996, 1997), she investigates in depth the arguments used by parity's supporters to overcome the obstacle of the rhetoric of universalism, which she describes as French republican democracy's "most enduring value" (2005: 1). Scott's main argument is based on a distinction between "two different registers of thinking" among the pro-parity discourses: that of "anatomical dualism", and that of "sexual difference". While the former remains faithful to the universalist idea of "abstract individual", the latter pertains, Scott argues, to an "essentialist" - and heterosexist perspective. The first type of discourse, that of "duality", was elaborated in Gaspard, Le Gall and Servan-Schreiber's book Au pouvoir, citoyennes! Liberté, Egalité, Parité (1992). According to Scott, the central innovation of the authors of Au pouvoir, citoyennes - whom she identifies as the "the original paritaristes" - was to inscribe sexual dualism in the terms of abstract universalism, since they insisted that humanity was dual but did not ascribe any substance to the sexual divide between human types. In emphasizing that "anatomical dualism could be distinguished from sexual difference, not as nature was from culture but as the abstract was from the concrete", their argument was, as said by Scott, "at the outset, neither essentialist nor separatist", but "rigorously universalist" (2005: 4). Identifying neither with the 
male figures of the citizens nor with their gender identity, the first "architects" of the concept of parity thereby overcame the "dilemma of difference" that French feminists had experienced, since the Revolution, whenever they demanded political inclusion. By sexing the abstract individual in order to "unsex" the political body, Scott argues, the original paritaristes managed to "refigure" universalism.

In the second half of the 1990s, as parity gained momentum and became the focus of a public controversy, the initial paritaristes lost control of the meaning of their demand. Scott assumes that the publication in 1998 of the pro-parity pamphlet Politique des sexes by philosopher Sylviane Agacinski (and wife of Lionel Jospin, then Prime Minister) paved the way for an "essentialist" turn in the debate on parity, provoking a "shift" from "duality" to "difference", from abstraction to "embodiment". "In [Agacinski's] thinking, men and women were not individuals who happened to be sexed, but necessarily opposites: husband and wife. The universal individual was not simply pluralized but replaced by the universal couple". Indeed, what clearly distinguishes Agacinski's book from the work of Gaspard and her co-authors is the close articulation that the former makes between sexual difference and heterosexuality through the metaphor of the couple and through the use of the term "mixity" (mixité), coined to mean "difference without hierarchy" (Scott, 2005: 118). In Agacinski's vision, sexual difference and heterosexuality are the two sides of the same coin, both grounded in nature (Agacinski, 1998: 108-109). From this, Scott draws the conclusion that there was a radical difference between Gaspard's and Agacinski's texts. By referring to the "discourse of the couple" rather than to that of the abstract individual, Agacinski "conflated anatomical duality and sexual difference while the founders of the movement sought to distinguish them". In so doing, Agacinski's work was “denying women the very equality as individuals that Gaspard and her colleagues sought" (Scott, 2005: 65-66). As Scott points out, this theoretical 
divergence translated into a political cleavage between Gaspard and Agacinski on the issue of access by same-sex couples to family rights. Indeed, during the debate over the "PaCS" (Pacte Civil de Solidarité, a civil union contract open to same-sex couples) that took place in the media and in Parliament at the same time as the debate on parity, Agacinski made a case against same-sex parenting, contrary to Gaspard and her co-authors. Agacinski's theory of sexual difference, developed in Politique des sexes, was not used only to justify parity. It was also the cornerstone of her strong argument against homosexual families.

\section{The essentialism of dualism}

Scott's Parité! includes a very acute comparison of Gaspard's and Agacinski's texts. Her point that there are important theoretical and political differences between the two texts is well taken. However, there are facets of her argument with which I must disagree. The statement that Gaspard et al.'s book is the "initial" conceptualization of parity is debatable: the dual nature of humanity and the need to redefine the notion of equality had been already formulated in Sledziewski's report for the Council of Europe in $1989^{10}$. But more importantly, Scott's assertion that there was a shift from an abstract, non-essentialist sexual "duality" to a substantive, essentialist sexual "difference" is open to question: it tends to under-estimate certain continuities between the two discourses.

First, the texts are both strongly linked to the rhetoric of abstraction, and reject the logic of embodiment. Both insist on the fact that the sexual divide is a universal receptacle filled by gender identities that are socially constructed through history and culture. Neither of them endorses a "differentialist" vision that would identify women as "a group with definable attributes" (Scott, 2005: 62). Scott rightly points out that Gaspard and her co-authors strongly 
reject any reference to biology and insist that gender is informed by socio-historical powerrelationships, while Agacinski focuses much more on the natural grounding of sexual difference, and refers to anthropology more frequently than to history to explain gender hierarchy. However, Agacinski also insists that there are no "essential" gender identities. In Politique des sexes, she writes: "there is no truth of sexual difference, but an interminable effort of humanity to give it a meaning, to interpret it, to cultivate it" (1998: 11-12). In short, the two texts both strategically distance themselves from "essentialist" or "differentialist" feminism, which has in any case been devalued and very marginal in the arena of French academic feminism since the 1970s (Delphy, 1995; Bereni, 2006a; Lépinard, 2007a). Moreover, as Scott herself points it out, Gaspard and Agacinski both reject the rhetoric of "women's interests" grounded on gender identity, since in their vision women cut across all interest groups. Gaspard and Agacinski both argue for figurative rather than substantive representation of women in politics, in order to remain faithful to the universalist framework of political representation (Rosanvallon, 1998). They both, then, explicitly distance themselves from the feminist theories that urge an enhanced "presence" of women in politics on the ground that female representatives would better convey the "perspectives" and/or “identities" of women (Young, 1990; Phillips, 1995; Mansbridge, 2001). In rejecting this rhetoric of "identity politics", they both manifest a determination to shape their claim as a genuine French product, not a US “import”. In sum, it would seem that the difference between the two as regards abstraction and embodiment is not as clear as Scott suggests.

Second, Gaspard's and Agacinski's texts both reassert gender binarism, and thus tend to depoliticize and essentialize the category of gender (Bereni, 2005). Both use the argument that no equation can be made between women and other minorities, precisely because of the immutable and pre-political dimension of sexual duality. Although this argument of dualism 
does not systematically lead to legitimizing the heterosexual basis of society, it does lead to emphasizing the complementarity between the two sexes, considered as the two sides of the same coin, quite apart from any historical and social power relationships. In this view, humanity, as well as democracy, are "unfinished" without their sexed dimension. While Agacinski explicitly stresses the idea of complementarity through the image of the heterosexual couple, Gaspard and her co-authors also tend to suggest it implicitly, through a metaphor of the human body, which Scott mentions in her book. As Claude Servan-Schreiber put it while presenting her book to a feminist seminar held in Paris in 1992, women and men are the "two legs" of a "single body", the human species, and are "not interchangeable" (quoted by Scott, 2005: 61). This refers to the complementary roles of the two sexes in the perpetuation of humanity: "Humanity would not exist without two distinct forms of sexed individuals. Women and men contribute together to the definition and the perpetuation of the species. They must contribute together, in parity, to the organization of the common life" (Gaspard and Servan-Schreiber, 1993: 2). In other terms, it is ultimately a pre-political argument, the bi-categorization of humanity, that requires a law imposing equal representation of the two sexes. The discourses of both Gaspard and Agacinski tend in the same move to make gender abstract and depoliticize it. As some feminist critiques of parity have pointed out, during and after the debate, on the ground of materialist feminist and/or queer theories, the idea that parity is rooted in a universal dualism is in itself a form of essentialism, even though there is no embodiment at stake (Varikas, 1994, 2006; Delphy, 1997; Bourcier, 2007). Indeed, by promoting such a discourse, parity advocates tend to obscure the idea that duality is as much a social product of power relationships as is hierarchy. In this sense, while there is a refiguration of universalism in pro-parity discourses, it is accompanied by a reaffirmation of the norm of gender binarism that precludes the proliferation of sexes, sexualities, and genders (Butler, 1990; Dorlin, 2006; Bourcier, 2007). Last but not least, such a vision leads to denying 
other oppressed minorities the benefits of the "breach" made by women "in the bulwark of the Republic" (Lépinard, 2007a: 392). By drawing a border between sexual difference and other social differences, this discourse leads to the homogenization of the category of gender, and neglects the intersection of gender and other categories, such as race and ethnicity.

\section{Conclusion}

This article has explored the discursive dimension of feminist challenges to existing malecentered political order through the case of the campaign for parity. After reviewing the history of demands for equalizing women's access to electoral office since the emergence of the second wave of feminism in France, shifting from quota to parity, it shows the discursive tactics used by proponents of parity to shape their claim within the terms of the dominant republican universalism, by renegotiating its meaning, by "refiguring" it, in Joan Scott's terms (2004, 2005). However, while Scott in her recent book suggests that initial parity activists managed to overcome the dilemma of sameness and difference, by sexing the abstract individual and in the same move unsexing the political body, it should be noted that their discourses do not rule out the risk of essentialism. There are more continuities between the arguments of "anatomical dualism" and of "sexual difference" than Scott suggests. Beyond their obvious theoretical and political divergences, Gaspard's and Agacinski's texts both tend to depoliticize sexual difference, by treating it as an immutable feature that cannot be compared to other social distinctions: in their perspective, it cuts across all groups and exists prior to and outside gender power relationships. Therefore, like many others in the long history of feminist challenges to the gender hierarchy, these parity campaigners both challenged and reinforced the dominant discourses, maintaining, rather than escaping, the "paradoxical" dimension of their struggles, as Scott mentioned in another context (1996). 


\section{Acknowledgments}

I would like to thank Amy Mazur, Daniel Sabbagh, and B. W. Corson for their helpful comments on a previous version of this text, although they are obviously not responsible for the thesis I developed here.

Date: 5 June 2007

Keywords: France; women's movements; gender parity; political representation; republican universalism.

Length: 8586 words (672 for notes and 1559 for references)

\section{References}

Agacinski, S. (1998) Politique des sexes, Paris: Seuil.

Agacinski, S. (1999) ‘Contre l'effacement des sexes’, Le Monde, 6 February.

Allwood, G. and Wadia, K. (2000) Women and Politics in France 1958-2000, London, New York: Routledge.

Amar, M. (ed.) (1999) Le piège de la parité. Arguments pour un débat, Paris: Hachette.

Appleton, A. and Mazur, A. G. (1993) 'Transformation or modernisation: the rhetoric of gender and party politics in France', in J. Lovenduski and P. Norris (eds.) Gender and Party Politics, London: Thousand Oaks, pp. 86-112.

Bacchi, C. L. (1999) Women, Policy and Politics. The Construction of Policy Problems, London: Thousand Oaks.

Bacchi, C. L. (2004) 'Policy and Discourse: Challenging the Construction of Affirmative Action as Preferential Treatment', Journal of European Public Policy 11(1):128-146.

Badinter, E. (1996) 'Non aux quotas de femmes', Le Monde, 12 June. 
Bard, C. (1995) Les filles de Marianne. Histoire des féminismes 1914-1940, Paris: Fayard.

Baudino, C. (2005) 'Gendering the Republican System: Debates on Women's Political Representation in France', in J. Lovenduski (ed.) State Feminism and Political Representation, New York: Cambridge University Press.

Beckwith, K. (2000) 'Beyond Compare? Women's Movements in Comparative Perspective', European Journal of Political Research 37:431-468.

Benford, R. and Snow, D. (2000) 'Framing Processes and Social Movements: An Overview and Assessment', Annual Review of Sociology 26:611-639.

Bereni, L. (2004) 'Le mouvement français pour la parité et l'Europe', in S. Jacquot and C. Woll (eds.) Les usages de l'Europe. Acteurs et transformations européennes, Paris: L'Harmattan, pp. 33-54.

Bereni, L. (2005) 'La parité, nouveau paradoxe des luttes féministes?', L'Homme et la société (158):219-226.

Bereni, L. (2006a) 'Les féministes françaises et la 'parité': permanences et renégociations des partitions héritées de la décennie 1970', in B. Lacroix, A. Cohen and P. Riutort (eds.) Les formes de l'activité politique. Eléments d'analyse sociologique (18ème-20ème siècles), Paris: PUF, pp. 123-142.

Bereni, L. (2006b) 'Lutter dans ou en dehors du parti? L'évolution des stratégies des féministes du Parti socialiste (1971-1997)', Politix 19(73):187-209.

Bereni, L. (2007) 'Du MLF au Mouvement pour la parité. La genèse d'une nouvelle cause dans l'espace de la cause des femmes', Politix 20 (78):107-132.

Bereni, L. and Lépinard, E. (2003) 'La parité, 'contresens de l'égalité'? Contraintes discursives et pratiques d'une réforme, Nouvelles Questions Féministes 22 (3):12-31.

Bereni, L, and Lépinard, E. (2004) “'Les femmes ne sont pas une catégorie’. Les stratégies de légitimation de la parité en France', Revue française de science politique 54(1):71-98. 
Bourcier, M.-H. (2007). Sexpolitiques: Queer zones 2, Paris: La Fabrique.

Bird, K. (2003) 'Who are the Women? Where are the Women? And What Difference Can They Make? Effects of Gender Parité in French Municipal Elections', French Politics 1(1):538.

Butler, J. (1990) Gender Trouble, New York: Routledge.

Della Porta, D. and Diani, M. (2006) Social movements: an introduction, 2d ed. Oxford: Blackwell.

Delphy, C. (1995) 'The Invention of French Feminism: An Essential Move', Yale French Studies (87):190-221.

Delphy, C. (1997) 'Pour en finir avec l'exclusion des femmes', Le Monde diplomatique, March.

Dorlin, E. (2006) La matrice de la race: généalogie sexuelle et coloniale de la nation française, Paris: La Découverte.

Fassin, E. (1999) 'The Purloined Gender. American Feminism in a French Mirror', French Historical Studies 22(1):113-138.

Ferree, M. M. (2003) 'Resonance and Radicalism: Feminist Framing in the Abortion Debates of the United States and Germany', American Journal of Sociology 109(2):304-344.

Fraisse, G. (1989) Muse de la raison, démocratie et exclusion des femmes en France, Aix-enProvence: Alinéa.

Fraisse, G. (1997) ‘La démocratie exclusive: un paradigme français’, Pouvoirs (82):5-16.

Furet, F. (1989) L'héritage de la Révolution française, Paris: Hachette.

Gaspard, F., Le Gall, A. and Servan-Schreiber, C. (1992) Au pouvoir, citoyennes! Liberté, Egalité, Parité, Paris: Seuil.

Gaspard, F. and Servan-Schreiber, C. (1993) 'De la fraternité à la parité', Le Monde, 19 February. 
Giraud, I. (2005) 'Mouvements des femmes et changements des régimes genrés de représentation politique au Québec et en France 1965-2004’ Ph.D. dissertation, Department of Political Science, University of Montréal (Canada) and University of Versailles-Saint-Quentin (France).

Giraud, I. and Jenson, J. (2001) 'Constitutionalizing Equal Access: High Hopes, Dashed Hopes?' in J. Klausen and C. S. Maier (eds.) Has Liberalism Failed Women?, New York: Palgrave.

Halimi, G. (1997) 'Parité hommes-femmes: un débat historique?', Le Monde, 7 March.

Jelen, C. (1997) 'La régression multiculturaliste’, Le Débat (97):137-143.

Jenson, J. and Sineau M. (1995) Mitterrand et les Françaises. Un rendez-vous manqué, Paris: Presses de la FNSP.

Klejman, L. and Rochefort, F. (1989) L'Egalité en marche. Le féminisme sous la Troisième République, Paris: Presses de la FNSP.

Kristeva, J. (1999), 'Le sens de la parité', Le Monde, 23 March.

Krook, M. L. (2007) 'National Solution or Model from Abroad? Analyzing International Influences on the Parity Movement in France', French Politics 5(1):3-19.

Landes, J. B. (1988) Women and the Public Sphere in the Age of the French Revolution, Ithaca: Cornell University Press.

Lépinard, E. (2006) 'Identity Without Politics: Framing the Parite Laws and their Implementation in French Local Politics', Social Politics 13(2):30-58.

Lépinard, E. (2007a) 'The Contentious Subject of Feminism: Defining Women in France from the Second Wave to Parity', Signs 32 (2):375-403.

Lépinard, E. (2007b) L'égalité introuvable. Les féministes, la parité et la République, Paris: Presses de Science po. 
Lovenduski, J. (ed.) (2005) State Feminism and Political Representation, Cambridge: Cambridge University Press.

Mansbridge, J. (2001) 'The Descriptive Political Representation of Gender: An AntiEssentialist Argument', in J. Klausen and C. S. Maier (eds.) Has Liberalism Failed Women?, New York: Palgrave.

Mazey, S. (2000) 'Introduction: Integrating gender - intellectual and 'real world' mainstreaming', Journal of European Public Policy 7(3):333-345.

Mazur, A. G. (2001) 'Drawing Lessons from the French Parité Movement' Contemporary French Civilization 25 (2).

Mazur, A. G. (ed.) (2001) State Feminism, Women's Movements, and Job Training: Making Democracies Work in the Global Economy, New York: Routledge.

Mazur, A. G. (2002) Theorizing Feminist Policy, London: Oxford University Press.

Mazur, A. G. (2005) 'Gendering the Fifth Republic', in A. Cole, P. Le Galès and J. D. Levy (eds.) Developments in French Politics, New York: Palgrave.

Minc, A. (1997) 'La journée des dupes’, Le Monde, 21 March.

Mossuz-Lavau, J. (1993) 'Le vote des femmes en France (1945-1993)', Revue française de science politique 43(4):673-689.

Mossuz-Lavau, J. (1998) Femmes/Hommes. Pour la parité, Paris: Presses de Sciences po.

Mossuz-Lavau, J., 'Les anti-paritaires se trompent', Le Monde, 25 February.

Murray, R. (2004) 'Why Didn't Parité Work? A Closer Examination of the 2002 Election Results', French Politics 2(3):347-362.

Nora, P. (1984) Les lieux de mémoire: 1, La République, Paris: Gallimard.

Observatoire de la parité entre les femmes et les hommes (1996), 'Rapport de la commission pour la parité entre les hommes et les femmes dans la vie politique, par Mme Gisèle Halimi', Observatoire de la parité: Paris. 
Offen, K. (1988) 'Defining Feminism: A Comparative Historical Approach', Signs (14):119157.

Offen, K. (2000) European Feminisms 1700-1950: A Political History, Stanford: Stanford University Press.

Opello, K. A. R. (2006) Gender Quotas, Parité Reform and Political Parties in France, Lexington Books.

Parti socialiste (1996) 'Les acteurs de la démocratie', Paris: Solfé communications.

Pateman, C. (1988) The Sexual Contract, Cambridge: Polity Press.

Phillips, A. (1995) The politics of Presence, Oxford: Oxford University Press.

Perrot, M. (1999), 'Oui, tenter cette expérience nouvelle', Le Monde, 25 February.

Picq, F. (1993) Libération des femmes: les années-mouvement, Paris: Le Seuil.

Pisier, E. (1999) 'Contre l'enfermement des sexes’, Le Monde, 11 February.

Praud, J. (1997) 'Feminizing Party Organizations: The Cases of the Parti Socialiste Français, the Parti Québécois and the Ontario New Democratic Party’ Ph.D. dissertation, Department of Political Science, University of Toronto (Canada).

Raynaud, P. (1992) 'De la tyrannie de la majorité à la tyrannie des minorités', Le Débat (69):50-59.

Riley, D. (1988) Am I That Name? Feminism and the Category of 'Women' in History, Minneapolis: University of Minnesota Press.

Rosanvallon, P. (1992) Le sacre du citoyen. Histoire du suffrage universel en France, Paris: Gallimard.

Rosanvallon, P. (1998) Le peuple introuvable. Histoire de la représentation démocratique en France, Paris: Gallimard.

Roudinesco, E. (1999) 'Une parité régressive', Le Monde, 11 February. 
Sawer, M., Tremblay, M. and Trimble, L. (eds.) (2006) Representing women in parliament: $a$ comparative study, London, New York: Routledge.

Schnapper, D. (1994) La communauté des citoyens: sur l'idée moderne de nation, Paris: Gallimard.

Scott, J. W. (1996) Only paradoxes to offer: French feminists and the rights of man, Cambridge: Harvard University Press.

Scott, J. W. (1997) 'La Querelle des Femmes' in the Late Twentieth Century', New Left Review (226):3-19.

Scott, J. W. (2004) 'French Universalism in the Nineties', Differences: A Journal of Feminist Cultural Studies 15(2):32-53.

Scott, J. W. (2005) Parité: Sexual Difference and the Crisis of French Universalism, Chicago: University of Chicago Press.

Sintomer, Y. (2001) 'Délibérer, participer, représenter. Vers une sociologie de la délibération politique' Thèse d'habilitation à diriger des recherches, Department of Sociology, University of Paris 5 (France).

Sledziewski, E. G. (1992) 'Rapport préparatoire au séminaire sur la 'démocratie paritaire’, in La démocratie paritaire. Quarante années d'activité du Conseil de l'Europe, Strasbourg: Editions du Conseil de l'Europe.

Spitz, J.-F. (1997) 'Républicanisme et droits de l'homme’, Le Débat (97):48-69.

Thébaud, F. (2001) 'Promouvoir les droits des femmes: ambitions, difficultés et résultats', in S. Berstein, P. Milza and J.-L. Bianco (eds.) Les années Mitterrand: les années du changement, Paris: Perrin.

Varikas, E. 1994. 'Refonder ou raccommoder la démocratie? Réflexions critiques sur la demande de la parité des sexes', French Politics and Society 12 (4):1-34.

Varikas, E. (2006) Penser le genre, Paris: PUF. 
Young, I. (1990) Justice and the Politics of Difference, Princeton: Princeton University Press.

${ }^{1}$ In the "Loi constitutionnelle no 99-569 du 8 juillet 1999 relative à l'égalité entre les femmes et les hommes", the French Parliament voted an amendment modifying two articles of the Constitution. First, to the article referring to sovereignty the following provision was added (article 3): "The law favors the equal access of women and men to electoral mandates and elective functions"; second, the article about political parties (article 4) was made to specify that they "contribute to the execution of the principle set forth in the last section of Article 3 under the conditions determined by the law" (Journal Officiel, 9 July 1999, 10175). The "Loi no 2000-493 du 6 juin 2000 tendant à favoriser l'égal accès des femmes et des hommes aux mandats électoraux et fonctions électives" provides 1) a legal requirement of parité for the party list system (most notably for local, regional and European elections) and 2) financial incentives through the public funding of political parties for the legislative elections. For elections using list systems (municipal, regional, European and some senatorial elections), parties are required to submit lists with equal numbers of men and women in a defined order. A financial incentive is used for the legislative elections (using a single member district electoral system): State subsidies to each party are reduced in proportion to the gap in the number of male and female candidates nationwide.

${ }^{2}$ In line with most comparative studies of women's movements (Offen, 1988; Beckwith, 2000; Mazur, 2001), I use the term women's movement(s) to name movements "...characterized by the primacy of women's gendered experiences, women's issues, and women's leadership and decision making" (Beckwith, 2000: 437); I refer to "feminists" or "feminist movements" to name groups or individuals seeking to "advance women's rights and/or status, however they are defined, and strike down genderbased hierarchies in society" (Mazur, 2001: 201).

${ }^{3}$ In 1993, Greece was the only European country to rank behind France as regards the political representation of women in the Parliament.

${ }^{4}$ However, these "first-wave" organizations arguing for an increased presence of women (such as the "Union Féminine Civique et Sociale" (UFCS) and the "Comité international de liaison des associations féminines" (CILAF)) never asked for quotas in the 1970s.

${ }^{5}$ See for example: Agacinski (1998, 1999), Fraisse (1997), Perrot (1999), Mossuz-Lavau (1998, 1999), Kristeva (1999).

${ }^{6}$ For example, a nation-wide poll published in the 28 October 1996 issue of the weekly magazine Elle showed that 59 percent of the French population found that the implementation of quotas would be "rather a good thing" to increase women's presence in political assemblies.

${ }^{7}$ The principle of "parité » was mentioned in the section entitled: "Le pouvoir des citoyens : de la décision confisquée à la décision partagée » (The power of citizens: from confiscated to shared decision).

${ }^{8}$ It must be noted that discourse-focused approaches do not systematically lead to an instrumental conception of the role of ideas. According to Bacchi, one should rather consider that activists are "in discourses", i.e. their interests are informed by "shared belief systems", and "use discourses" i.e. "consciously deploy particular discursive frameworks for desired political purposes" (Bacchi, 2004: 129). One thus needs to understand the discursive work of groups partly as 1) a conscious manipulation of the dominant frameworks of meaning in order to increase the cultural "resonance" of their claims and thus their chances of success, and as 2) an embedded expression of these beliefs and values.

${ }^{9}$ Some opponents to parity also raised a "leftist" critique, arguing that the reform would benefit only women who were already privileged (Sintomer, 2001; Bereni, 2006; Lépinard, 2007b).

${ }^{10}$ In her report, Sledziewski wrote: "the definition of the human subject cannot omit the sexual difference, since it is as a man or a woman that this subject realizes her/his humanity, or, more radically, that he/she is. (...) The equal intervention of female citizens in the city's affairs is now considered as a necessary condition of the achievement of democracy. A democracy without women is not an imperfect democracy anymore. It is not a democracy at all" (Sledziewski, 1992:23;27). 